OPEN ACCESS

Edited by:

Ulrich Blank,

Institut National de la

Santé et de la Recherche

Médicale (INSERM),

France

Reviewed by:

Ryo Suzuki,

Kanazawa University,

Japan

Axel Lorentz,

University of Hohenheim,

Germany

*Correspondence:

Pavel Dráber

paveldra@img.cas.cz

Specialty section:

This article was submitted to

Molecular Innate Immunity,

a section of the journal

Frontiers in Immunology

Received: 20 April 2018 Accepted: 25 June 2018

Published: 09 July 2018

Citation:

Rubíková Z, Sulimenko V, Paulenda T and Dráber P (2018) Mast Cell Activation and

Microtubule Organization Are Modulated by Miltefosine Through

Protein Kinase C Inhibition.

Front. Immunol. 9:1563. doi: 10.3389/fimmu.2018.01563

\section{Mast Cell Activation and Microtubule Organization Are Modulated by Miltefosine Through Protein Kinase C Inhibition}

\author{
Zuzana Rubíková ${ }^{1}$,Vadym Sulimenko ${ }^{1}$, Tomáš Paulenda ${ }^{2}$ and Pavel Dráber ${ }^{1 *}$ \\ 'Department of Biology of Cytoskeleton, Institute of Molecular Genetics, Czech Academy of Sciences, Prague, Czechia, \\ ${ }^{2}$ Department of Signal Transduction, Institute of Molecular Genetics, Czech Academy of Sciences, Prague, Czechia
}

Mast cells play an effector role in innate immunity, allergy, and inflammation. Antigenmediated activation of mast cells initiates signaling events leading to $\mathrm{Ca}^{2+}$ response and the release of inflammatory and allergic mediators from granules. Diseases associated with deregulated mast cell functions are hard to treat and there is an increasing demand for new therapeutic strategies. Miltefosine (hexadecylphosphocholine) is a new candidate for treatment of mast cell-driven diseases as it inhibits activation of mast cells. It has been proposed that miltefosine acts as a lipid raft modulator through its interference with the structural organization of surface receptors in the cell membrane. However, molecular mechanisms of its action are not fully understood. Here, we report that in antigen-activated bone marrow-derived mast cells (BMMCs), miltefosine inhibits degranulation, reorganization of microtubules, as well as antigen-induced chemotaxis. While aggregation and tyrosine phosphorylation of IgE receptors were suppressed in activated cells pre-treated with miltefosine, overall tyrosine phosphorylation levels of Lyn and Syk kinases, and $\mathrm{Ca}^{2+}$ influx were not inhibited. In contrast, lipid raft disruptor methyl- $\beta$-cyclodextrin attenuated the $\mathrm{Ca}^{2+}$ influx. Tagged-miltefosine rapidly localized into the cell interior, and live-cell imaging of BMMCs with labeled intracellular granules disclosed that miltefosine inhibited movement of some granules. Immunoprecipitation and in vitro kinase assays revealed that miltefosine inhibited $\mathrm{Ca}^{2+}$ - and diacylglycerolregulated conventional protein kinase $\mathrm{C}$ (CPKC) isoforms that are important for mast cell degranulation. Inhibition of cPKCs by specific inhibitor Ly333531 affected activation of BMMCs in the same way as miltefosine. Collectively, our data suggest that miltefosine modulates mast cells both at the plasma membrane and in the cytosol by inhibition of cPKCs. This alters intracellular signaling pathway(s) directed to microtubules, degranulation, and migration.

Keywords: bone marrow-derived mast cells, cell activation, microtubules, miltefosine, protein kinase C

\footnotetext{
Abbreviations: $\mathrm{Ab}(\mathrm{s})$, antibody(ies); $\mathrm{Ag}$, antigen; $\mathrm{BMMC}$, bone marrow-derived mast cell; $\mathrm{BSA}$, bovine serum albumin; DNP, dinitrophenyl; FceRI, high affinity IgE receptor; Fura-2-AM, Fura-2-acetoxymethyl ester; HRP, horseradish peroxidase; ITAMs, immunoreceptor tyrosine-based activation motifs; $\mathrm{M} \beta \mathrm{CD}$, methyl- $\beta$-cyclodextrin; mAb, monoclonal antibody; 4 -NAG, 4-nitrophenyl N-acetyl- $\beta$-D-glucosaminide; $c \mathrm{PKCs}, \mathrm{Ca}^{2+}$ - and diacylglycerol-regulated conventional protein kinases; PI3K, phosphatidylinositol 3-kinase; SOCE, store-operated $\mathrm{Ca}^{2+}$ entry; WGA, wheat germ agglutinin.
} 


\section{INTRODUCTION}

Mast cells play a pivotal role in innate immunity, allergy, and inflammation. Diseases associated with deregulated mast cell functions are hard to treat, and so the demand for new and better treatments targeting mast cell activation pathways increases. Mast cells express on their surfaces receptors with a high affinity for IgE (FceRIs). Aggregation of FceRIs by multivalent antigen (Ag)-IgE complexes leads to activation of signaling pathways resulting in the release of $\mathrm{Ca}^{2+}$ from the endoplasmic reticulum (ER) and subsequent activation of store-operated $\mathrm{Ca}^{2+}$ entry (SOCE). The influx of free $\mathrm{Ca}^{2+}$ is important for replenishment of $\mathrm{Ca}^{2+}$ in ER, but also works as a second messenger for further signaling. Activation events result in the release of preformed granule mediators and de novo synthesis and secretion of bioactive compounds, including lipid mediators, cytokines, and chemokines (1). Besides that, mast cell activation by FceRI aggregation is accompanied with changes in cell morphology, enhanced adhesion, and migration. It was reported that activation of mast cells induces increased formation of microtubules $(2,3)$ and their reorganization into protrusions containing microtubules (microtubule protrusions) $(4,5)$. Independent of FceRI aggregation, the activation events can be mimicked by non-specific activators, such as protein tyrosine phosphatase inhibitor pervanadate, inhibitor of ER $\mathrm{Ca}^{2+}$-ATPase pumps thapsigargin (4), or calcium ionophore A23187 (6).

A promising candidate for novel therapeutic strategies in mast cell-driven diseases is miltefosine (hexadecylphosphocholine), as it inhibits activation in human mast cells (7) and reduces disease progression in patients with mast cell-derived mastocytosis (8), urticaria (9), and atopic dermatitis (10). Moreover, miltefosine is used as a treatment of leishmaniasis (11) and free-living amebae infections (12).

Miltefosine is a derivative of plasmalogen phospholipids (13), which is taken up by cells in a lipid raft-dependent manner (14). It has been proposed that miltefosine acts as a lipid raft modulator through its interference with the structural organization of surface receptors in the cell membrane (15). Besides that, it modulates different signaling pathways. It has been reported that miltefosine affects phosphatidylcholine synthesis and stress-activated protein kinase/Jun $\mathrm{N}$-terminal kinase apoptotic pathway (16), phosphatidylinositol 3-kinase (PI3K)/Akt survival pathway (17), as well as the activity of phospholipase $C \beta$ (18), phospholipase D (19), and protein kinase C (PKC) (20). Despite this knowledge, the molecular mechanisms of miltefosine action in mast cells remain poorly understood.

To get deeper insight into the function(s) of miltefosine in mast cells we evaluated early stages of cell activation after crosslinking of FceRIs, $\mathrm{Ca}^{2+}$ influx, degranulation, microtubule reorganization, and migration in bone marrow-derived mast cells (BMMCs) treated with miltefosine. Moreover, we localized miltefosine in BMMCs and evaluated its effect on intracellular granule movement. Our results indicate that miltefosine does not regulate mast cells only through lipid raft modulation, but also by inhibition of $\mathrm{Ca}^{2+}$-dependent PKCs affecting cytosolic signaling pathways that modulate microtubule organization, degranulation, and migration of mast cells.

\section{MATERIALS AND METHODS}

\section{Reagents}

Calcium ionophore A23187, dinitrophenyl-albumin (DNPalbumin), fibronectin, Ly333531, methyl- $\beta$-cyclodextrin (M $\beta C D)$, miltefosine, probenecid, puromycin, thapsigargin, Trypan blue, and 4-nitrophenyl $\mathrm{N}$-acetyl- $\beta$-D-glucosaminide (4-NAG) were from Sigma-Aldrich (St. Louis, MO, USA). Fura-2-acetoxymetyl ester (Fura-2-AM) was purchased from Invitrogen (Carlsbad, CA, USA). Collagen I was from Advanced BioMatrix (San Diego, CA, USA). Protein A Sepharose ${ }^{\mathrm{TM}}$ CL-4B was from GE Healthcare Life Sciences (Chicago, IL, USA) and SuperSignal WestPico Chemiluminescent reagent was from Pierce (Rockford, IL, USA). Wheat germ agglutinin (WGA) conjugated with Alexa Fluor 555 (WGA-AF555) was purchased from Molecular Probes (Eugene, OR, USA).

\section{Antibodies}

Mouse monoclonal antibody (mAb) TUB 2.1 (IgG1) to $\beta$-tubulin conjugated with indocarbocyanate (Cy3), mouse $\mathrm{mAb}$ SPE-7 (IgE) specific for DNP, and mouse mAb PY-20 (IgG2b) to phosphotyrosine were from Sigma-Aldrich (St. Louis, MO, USA). $\alpha$-Tubulin was detected with rabbit Ab (GTX15246) from Genetex (Irvine, CA, USA). Rabbit polyclonal Ab to mouse IgE was described previously (21) and rabbit $\mathrm{mAb}$ to $\mathrm{PKC} \alpha \beta \gamma$ was from Abcam (Cambridge, UK). Mouse mAb SKB1 (IgG) to Akt and mouse mAb 4G10 (IgG2b) to phosphotyrosine conjugated with horseradish peroxidase (HRP) were from Upstate Laboratories (Syracuse, NY, USA). Rabbit polyclonal Abs to Lyn (Lyn44), Syk (N-19), and phospho-Akt (Ser $\left.{ }^{473}\right)$ were from Santa Cruz Biotechnology (Dallas, TX, USA). Rabbit Ab to phospho-Akt $\left(T h r^{308}\right)$ was from Cell Signaling (Danvers, MA, USA). Preparation of rabbit Ab to LAT and mouse mAb LAT.1D1 (IgG2a) to LAT were described previously $(22,23)$. Mouse mAb TU-32 (IgG1) to $\gamma$-tubulin was described previously (24). Anti-mouse and anti-rabbit Abs conjugated with HRP were from Promega Biotec (Madison, WI, USA). Anti-mouse Ab conjugated with DyLight549 was from Jackson ImmunoResearch Laboratories (West Grove, PA, USA).

\section{Cell Cultures and Activation}

Primary culture of bone marrow-derived mast cells from BALB/c and cells of mouse BMMC lines (25) were prepared and cultured as previously described (4). For immunofluorescence experiments, cells were overlaid on fibronectin-coated coverslips (4). Cells were only sensitized with DNP-specific IgE (mouse mAb SPE-7; $1 \mu \mathrm{g} / \mathrm{ml}$ ) for $4 \mathrm{~h}$ in culture medium without $10 \%$ WEHI-3 cell supernatant and activated with Ag (DNP-albumin conjugate; $1 \mu \mathrm{g} / \mathrm{ml} ; 30-40 \mathrm{~mol} \mathrm{DNP} / \mathrm{mol}$ albumin) for $3 \mathrm{~min}$ in culture medium with $0.5 \%$ FCS and without $10 \%$ WEHI-3 cell supernatant (activation medium) (4). Alternatively, sensitized cells were activated by crosslinking of bound IgE with anti-mouse $\mathrm{Ab}$ conjugated with DyLight549 $(1.5 \mu \mathrm{g} / \mathrm{ml})$ for $20 \mathrm{~min}$ at $37^{\circ} \mathrm{C}$ as described previously (26). Cells were also activated for $15 \mathrm{~min}$ at $37^{\circ} \mathrm{C}$ in activation medium containing $2 \mu \mathrm{M}$ thapsigargin or pervanadate as described previously (4) or $0.5 \mu \mathrm{M}$ ionophore 
A23187. Control human retinal pigment epithelial cells hTERTRPE1 (RPE1) (Dr. M. Bonhivers, Université Bordeaux, Bordeaux, France) were cultured as described previously (27).

Cells were pre-treated with miltefosine at final concentration $5-25 \mu \mathrm{M}$ for $15-60 \mathrm{~min}$ at $37^{\circ} \mathrm{C}$ prior to activation. In some cases, cells were incubated with 1-15 $\mu \mathrm{M}$ BODIPY-labeled miltefosine (MT-11c-6EtBDPY) (28) for $1-60 \mathrm{~min}$ at $37^{\circ} \mathrm{C}$. If not specified otherwise, cells were pre-treated with miltefosine or BODIPY-miltefosine at final concentration of $15 \mu \mathrm{M}$ for $15 \mathrm{~min}$, and compounds were also present in the course of activation. Alternatively, cells were incubated under the same conditions with 0.015-10 mM M 3 CD or 0.5-15 $\mu \mathrm{M}$ Ly333531.

Trypan blue exclusion test was used to evaluate the effect of miltefosine treatment on viability of BMMCs.

\section{Reverse Transcription PCR}

Total RNAs from BMMCs or mouse brain were isolated by the RNeasy Mini kit (QIAGEN, Valencia, CA, USA) and converted to cDNAs using the SuperScript ${ }^{\circledR}$ VILO cDNA Synthesis Kit (Thermo Fisher Scientific, Waltham, MA, USA) according to the manufacturer's protocol. PCRs were performed with primers specific for mouse PKC $\alpha$ (Prkca, NM_011101.3; forward 5'-GTCTCAGAGCTAATGAAGATG-3' and reverse 5'-TTGGCTTTCTCAAACTTCTG-3'), PKC $\beta$ (Prkcb, NM_008855.2, and NM_001316672.1; primers anneal to all transcript variants; forward 5'-GAATCAGACAAA GACAGAAGAC-3' and reverse 5'-CTTAGTAACTTGAACCA GCC-3'), and PKC $\gamma$ (Prkcg; NM_011102.4, NM_001291434.1; primers anneal to all transcript variants; forward 5'-AATGTACC GGTGGCCGATGCT-3'; and reverse 5'-AGGCGGTCCGG AGTCTGAAA-3'). Mouse actin (Actb; NM_007393; forward 5'-GGACCTGACGGACTACCTCATG-3' and reverse 5'-TCTTTGATGTCACGCACGATTT-3') was used as housekeeping gene. All primers (Sigma-Aldrich) were tested in silico by NCBI BLAST to amplify specific targets. The PCR efficiencies for tested PKC isoforms were similar. Quantitative PCRs were performed in the LightCycler 480 System (Roche, Mannheim, Germany) as described previously (29). Amplified fragments were separated on $2 \%$ agarose gel and stained by GelRed Nucleic Acid Gel Stain (Biotium, Fremont, CA, USA).

\section{Determination of Intracellular $\mathbf{C a}^{2+}$ Concentrations}

Changes in the level of free intracellular $\mathrm{Ca}^{2+}$ were measured using Fura-2-AM as a cell permeant calcium reporter following protocol for sample handling as described in Ref. (4). Intracellular free $\mathrm{Ca}^{2+}$ was measured in microplate reader Infinite M200 (Tecan, Männedorf, Switzerland) as a ratio of Fura emissions at $510 \mathrm{~nm}$ after excitation with 340 and $380 \mathrm{~nm}$ (340/380) lasers at the indicated time points. After measurement of the $\mathrm{Ca}^{2+}$ basic level, activation was triggered by addition of Ag, thapsigargin, or ionophore A23187.

\section{Degranulation Assay}

The degree of degranulation was quantified as the release of $\beta$-hexosaminidase from Ag-, thapsigargin-, pervanadate-, or ionophore-activated cells, using 4-NAG as substrate (2). The extent of degranulation was calculated as follows: absorbance of culture supernatant $\times 100 /$ absorbance of total cell lysate and normalized to control cells.

\section{Immunoprecipitations, Kinase Assay, and Immunoblotting}

For immunoprecipitation experiments, BMMCs $\left(1 \times 10^{7}\right.$ cells per reaction) were activated with Ag or thapsigargin. Immunoprecipitation was performed as previously described (30). Cell extracts were incubated with protein A beads saturated with (i) Ab to IgE; (ii) Ab to PKC $\alpha \beta \gamma$; (iii) Ab to Lyn; (iv) Ab to Syk; (v) Ab to LAT; or (vi) immobilized protein A alone. In vitro kinase assay was essentially performed as described and the ${ }^{32} \mathrm{P}$-labeled proteins were detected by autoradiography using the Amersham Typhoon scanner (GE Healthcare Europe $\mathrm{GmbH}$, Freiburg, Germany). Whole cell extract preparation, gel electrophoresis, and immunoblotting were described elsewhere (4). Abs to $\gamma$-tubulin (in the form of spent culture supernatant) and PKC $\alpha \beta \gamma$ were diluted 1:2 and 1:3,000, respectively. Abs to Lyn, Syk, LAT (mAb LAT1.D1), Akt, phospho-Akt (Thr $\left.{ }^{308}\right)$, and phospho-Akt $\left(\mathrm{Ser}^{473}\right)$ were diluted 1:2,000, 1:2,000, 1:2,000, 1:2,000, 1:500, and $1: 1,000$, respectively. Phosphotyrosine was detected by antiphosphotyrosine mAb $4 \mathrm{G} 10$ conjugated with HRP (dilution $1: 2,000$ ) or by mAb PY-20 (dilution 1:2,000). Bound primary antibodies were detected after incubation of the blots with HRPconjugated secondary Abs diluted 1:10,000. HRP signal was detected with chemiluminescent reagents and the LAS 3000 imaging system (Fujifilm, Düsseldorf, Germany). AIDA image analyzer (ver.4) software (Raytest, Straubenhardt, Germany) was used for quantification of signals from autoradiographs and immunoblots.

\section{Chemotaxis and Cell Migration Assay}

Chemotaxis and cell migration assays were performed in $\mu$-Slide Chemotaxis $^{3 \mathrm{D}}$ chambers according to the protocols described elsewhere (31). In the case of chemotaxis assay, BMMCs were sensitized prior to seeding and one reservoir of each chamber was supplied with $\mathrm{Ag}$ at concentration $100 \mathrm{ng} / \mathrm{ml}$. In miltefosine-, M $\beta C D$-, or Ly333531-treated cells, the drug was added to collagen I gel and to reservoirs and was present during the gel polymerization and imaging.

\section{Immunofluorescence Microscopy}

Immunofluorescence microscopy was performed with cells attached to fibronectin-coated coverslips fixed as described (32). TUB 2.1 mAb conjugated with Cy3 was diluted 1:600. DyLight549conjugated anti-mouse $\mathrm{Ab}$ was diluted 1:500. To visualize FceRI aggregation, cells were fixed without Triton X-100 extraction to preserve intact cell membranes. The preparations were examined with an Olympus A70 Provis microscope (Olympus, Hamburg, Germany) or in the Delta Vision Core system (Applied Precision, Issaquah, WA, USA). The conjugated secondary Ab did not give any detectable staining. Live cell imaging of BMMCs labeled with $15 \mu \mathrm{M}$ BODIPY-miltefosine was performed in the Delta Vision Core system. Images were deconvolved by integrated 
deconvolution software. Determination of the number of cells that responded to activation events by generation of microtubule protrusions was done as described previously. Three experiments were performed, and in each experiment 300-500 cells were examined (4).

\section{Time-Lapse Imaging}

For chemotaxis and cell migration assay, cells were imaged with a Leica DMI6000 inverted microscope at $37^{\circ} \mathrm{C}$ and $5 \% \mathrm{CO}_{2}$. Time-lapse sequences of bright-field images were taken for 7 (chemotaxis) or $3 \mathrm{~h}$ (cell migration), at $1 \mathrm{~min}$ intervals with the intensity of 71 and exposure time $6 \mathrm{~ms}$. To evaluate the intracellular granule movement, cells were incubated with WGA-AF555 $(5 \mu \mathrm{g} / \mathrm{ml})$ for $10 \mathrm{~min}$ and time-lapse sequences were acquired in the Delta Vision Core System.

\section{Image Analysis}

For analysis of the granule movement, time-lapses were registered by StackReg in ImageJ and processed using ImageJ Kymograph plugin. Fluorescence intensity of FceRI aggregation was quantified using ImageJ based on the mean pixel intensity of each cell.

Chemotactic response and cell migration were analyzed from time-lapse movies as described previously (31). Cells were tracked in the MetaMorph program using the Track Object application. The data were processed by Chemotaxis and Migration Tool in ImageJ. Analysis was performed for 7 and $3 \mathrm{~h}$ imaging.

\section{Statistical Analysis}

All data are presented as mean \pm SD or SE, as indicated. For statistical analysis, the two-tailed, unpaired Student's $t$-test was applied.

\section{RESULTS}

\section{Degranulation in Activated BMMCs Is Inhibited by Miltefosine}

Miltefosine is known to inhibit mediator release in human mast cells (7). To test whether the same holds true for mouse BMMCs, the degree of degranulation in miltefosine pre-treated and activated BMMCs was determined. Cells were incubated with different concentrations of miltefosine in the range of 5-25 $\mu \mathrm{M}$ for $15 \mathrm{~min}$. The release of $\beta$-hexosaminidase in cells activated by FceRI aggregation (Figure 1A) decreased in a miltefosinedose-dependent manner. Alternatively, BMMCs were activated by thapsigargin. Miltefosine decreased the level of degranulation in a dose-dependent manner as well (Figure 1B). A less prominent inhibitory effect was observed after stimulation of BMMCs by pervanadate (Figure 1C). The least effect ( $21 \%$ inhibition at miltefosine concentration $25 \mu \mathrm{M}$ ) was detected when the cells were activated by calcium ionophore A23187 (data not shown). As miltefosine was proposed to act as a lipid raft modulator (15), we treated BMMCs with $\mathrm{M} \beta C D$, a typical lipid raft disruptor. $\mathrm{M} \beta \mathrm{CD}$ inhibited $\beta$-hexosaminidase release in cells activated by
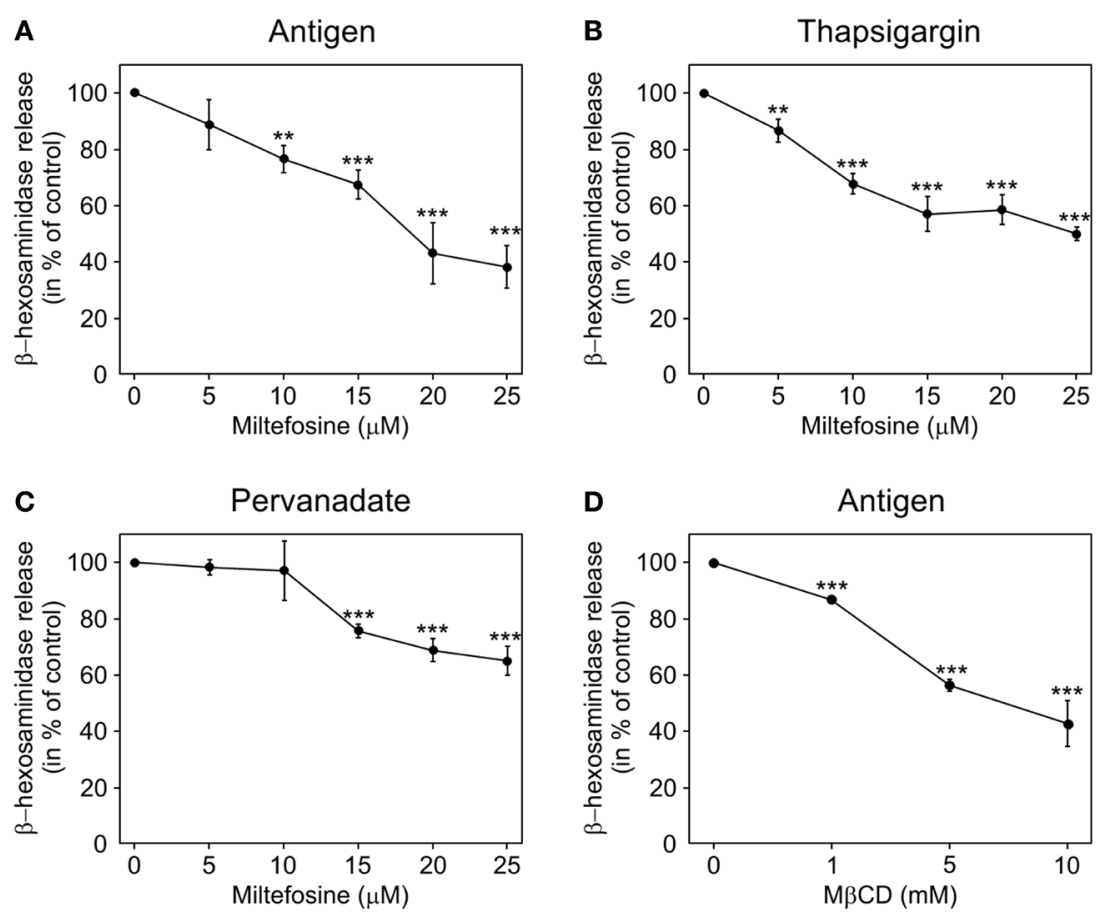

FIGURE 1 | Miltefosine and methyl- $\beta$-cyclodextrin (M $\beta C D$ ) inhibit degranulation in activated bone marrow-derived mast cells (BMMCs). BMMCs pre-incubated with different concentrations of miltefosine (5-25 $\mu \mathrm{M})(\mathbf{A}-\mathbf{C})$ or $\mathrm{M} \beta \mathrm{CD}(1-10 \mathrm{mM})$ (D) were activated and degranulation was measured by $\beta$-hexosaminidase release. (A,D) lgE-sensitized cells were activated by high affinity lgE receptor aggregation with Ag. (B) Cells activated with thapsigargin. (C) Cells activated with pervanadate. Values represent mean $\pm \mathrm{SD}(n=3) ;{ }^{* *} p<0.01$ and ${ }^{* * *} p<0.001$. 
FceRI aggregation (Figure 1D) at substantially higher concentrations. The maximal inhibitory effect ( $\sim 60 \%$ inhibition) was observed at M $\beta C D$ concentration of $10 \mathrm{mM}$.

To evaluate whether inhibitory effect of miltefosine is due to changes in cell viability, we performed Trypan blue exclusion test. Viability of BMMCs treated with $15 \mu \mathrm{M}$ miltefosine for 15 , 30 , and $60 \mathrm{~min}$ in activation medium was $94.7 \pm 7 ; 94.6 \pm 7$, and $95.0 \pm 7 \%$ (mean $\pm \mathrm{SD} ; n=3$ ), respectively. As viability of BMMCs treated with $25 \mu \mathrm{M}$ miltefosine fell to $\sim 50 \%$, miltefosine was used at a maximal concentration of $15 \mu \mathrm{M}$ in the following experiments.

Taken collectively, miltefosine inhibits degranulation in mouse BMMCs activated either specifically by FceRI aggregation, or unspecifically by thapsigargin, pervanadate, or calcium ionophore.

\section{Miltefosine Modulates Microtubule Organization and Cell Migration in BMMCs}

Generation of protrusions containing microtubules is a characteristic feature of activated BMMCs attached to fibronectin (4). To evaluate the effect of miltefosine on generation of such protrusions, cells were pre-treated for 15 min with $15 \mu \mathrm{M}$ miltefosine, and thereafter activated by Ag, thapsigargin, calcium ionophore, or pervanadate in the presence of miltefosine. Control cells activated by FceRI aggregation using Ag (Figure 2Aa), thapsigargin (Figure 2Ac), calcium ionophore (Figure 2Ae), or pervanadate (data not shown) formed typical microtubule protrusions. On the other hand, cells activated in the presence of miltefosine by FceRI aggregation using $\mathrm{Ag}$ (Figure 2Ab), thapsigargin (Figure 2Ad), calcium ionophore (Figure 2Af), or pervanadate (data not shown) were not capable to form microtubule protrusions. Statistical evaluation revealed a dose-dependent inhibitory effect of miltefosine on the formation of microtubule protrusions (Figure 2B). Activation of cells with Ag, thapsigargin, calcium ionophore, or pervanadate showed a similar response to miltefosine treatment, and already $5 \mu \mathrm{M}$ miltefosine significantly inhibited formation of microtubule protrusions. Higher concentrations of miltefosine resulted in changes of cell morphology; cells were more spherical. Generation of microtubule protrusions was not affected when cells were activated by Ag in the presence of $15 \mu \mathrm{M} M \beta C D$. When cells were activated by $\mathrm{Ag}$ in the presence of $5 \mathrm{mM} \mathrm{M} \beta \mathrm{CD}$, the generation of protrusions reached $43 \pm 14 \%$ (mean $\pm \mathrm{SD} ; n=2$ ) of the control, and in the presence of $10 \mathrm{mM} \mathrm{M} \beta \mathrm{CD}, 3.4 \pm 3 \%$ (mean $\pm \mathrm{SD} ; n=2$ ) of the control. Therefore, M $\beta \mathrm{CD}$ has to be used at substantially higher concentration to get a similar effect as miltefosine.

The activation with Ag, thapsigargin, or pervanadate was also performed in primary culture of BMMCs from BALB/c mice. Similarly as in the BMMC cell line, miltefosine inhibited generation of microtubule protrusions in these cells (data not shown). Miltefosine at concentration $5 \mu \mathrm{M}$ did not distinctly affect microtubules in adherent RPE1 cells (Figure 2Ca,b). At higher miltefosine concentration $(15 \mu \mathrm{M})$, cells started to round up (Figure 2Cc). These data document that miltefosine, even at low concentrations, strongly affects microtubule organization after cell activation both in BMMCs in the form of primary culture or cell line. On the other hand, $5 \mu \mathrm{M}$ miltefosine did not affect microtubules in RPE1 or osteosarcoma U2OS cells (data not shown).

Ag-induced chemotactic response is essential for local accumulation of mast cells in the body, where they might perform their physiological roles. To study the effect of miltefosine on the migration of BMMCs to Ag, chemotaxis assays were performed. As shown in a representative experiment, miltefosine inhibited chemotaxis toward Ag. Moreover, tracks in miltefosine-treated cells were substantially shorter when compared to control cells (Figure 2D). The cell migration assay without chemoattractant revealed that both mean cell velocity (Figure 2E, left panel) and mean accumulated distance (Figure 2E, right panel) of all moving cells decreased in cells treated with $15 \mu \mathrm{M}$ miltefosine. On the other hand, cell motility was not affected by $1 \mathrm{mM} \mathrm{M} \beta C D$, and an inhibitory effect was observed only at $10 \mathrm{mM}$ concentration of M $\beta C D$ (data not shown). These data suggest that inhibition of $\mathrm{Ag}$-induced chemotaxis by miltefosine is due to suppression of cell motility.

\section{Miltefosine Affects Tyrosine Phosphorylation and Aggregation of FceRI Receptors in Activated BMMCs}

It has been reported that miltefosine, as a lipid raft modulator, could interfere with the structural organization of FceRI receptors in activated mast cells and thus inhibit downstream signaling events (15). Because protein tyrosine phosphorylation plays an essential role in propagation of signals in BMMCs activated by FceRI aggregation, we evaluated the overall protein tyrosine phosphorylation level (P-Tyr) in control and miltefosine pretreated cells activated by Ag-mediated FceRI aggregation. While the P-Tyr level increased in Ag-activated cells when compared to non-activated cell controls (Figure 3A, lane 3), it decreased in cells treated with miltefosine (Figure $\mathbf{3 A}$, lane 4). It is well established that BMMC activation by Ag proceeds through tyrosine phosphorylation of immunoreceptor tyrosine-based activation motifs (ITAMs) located on the cytoplasmic tails of FceRI $\beta$ and $\gamma$ subunits (33). We found that BMMCs activated with Ag showed a significantly increased level of P-Tyr on FceRI (Figure 3B, lane 6) when compared with non-activated cells (Figure 3B, lanes 4-5). Phosphorylation of FceRI in activated cells clearly decreased in the presence of miltefosine (Figure 3B, lane 7). Quantification of overall P-Tyr levels and FceRI receptor P-Tyr levels in activated and miltefosine-treated cells is shown in Figures S1A,B in Supplementary Material. These findings were corroborated by immunofluorescence staining of IgE bound to FceRI receptors. BMMCs sensitized with $\operatorname{IgE}$ and activated with Ag showed clear aggregation of the bound IgE (Figure 3Ca). The same results were obtained when the bound IgE was aggregated with anti-Ig Ab (Figure 3Cc). However, when the cells were pretreated with miltefosine, aggregation with either $\mathrm{Ag}$ (Figure $3 \mathrm{Cb}$ ) or anti-Ig Ab (Figure 3Cd) was substantially suppressed. Image analysis revealed that the staining intensity of miltefosine-treated cells activated by crosslinking of bound IgE by Ag or by antimouse Ig Ab was significantly lower when compared to control cells (Figure 3D). These data directly demonstrate that miltefosine inhibits aggregation and tyrosine phosphorylation of FceRI receptors at the plasma membrane in activated BMMCs. 


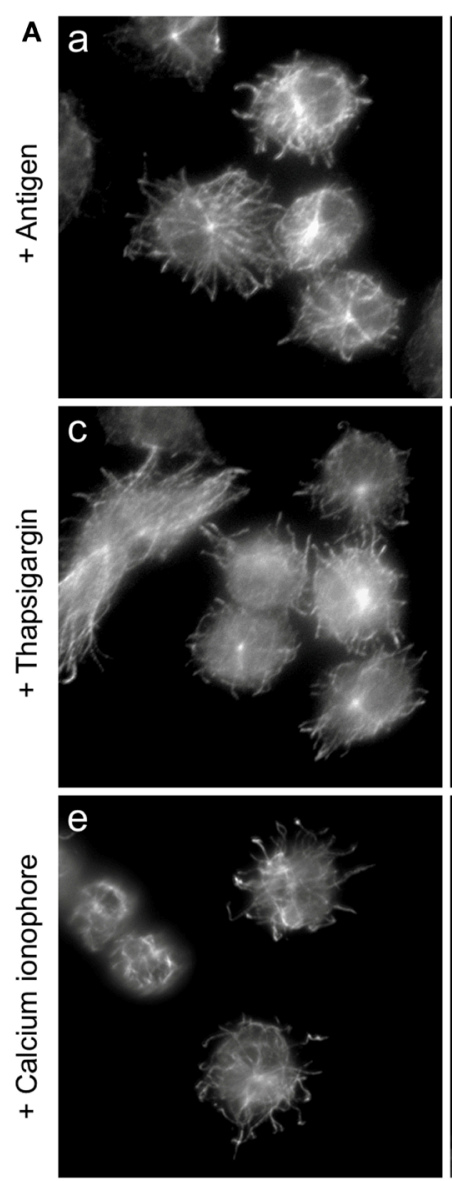

- Miltefosine
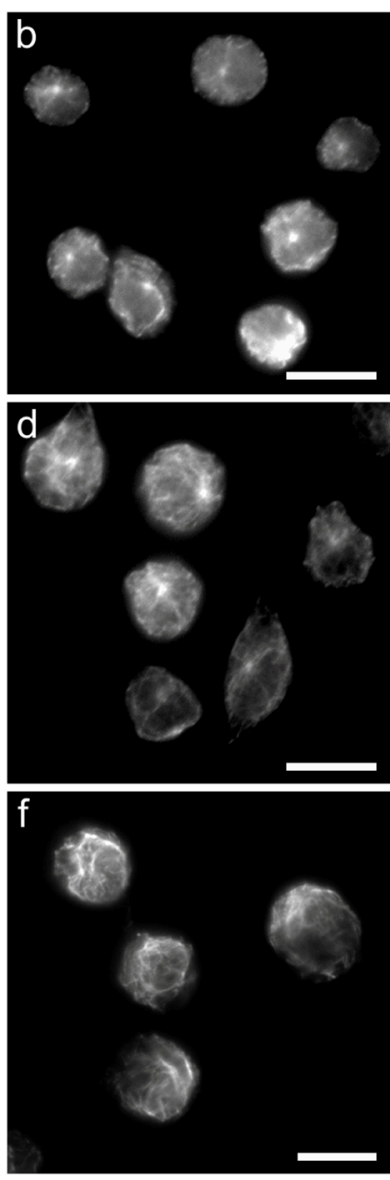

+ Miltefosine
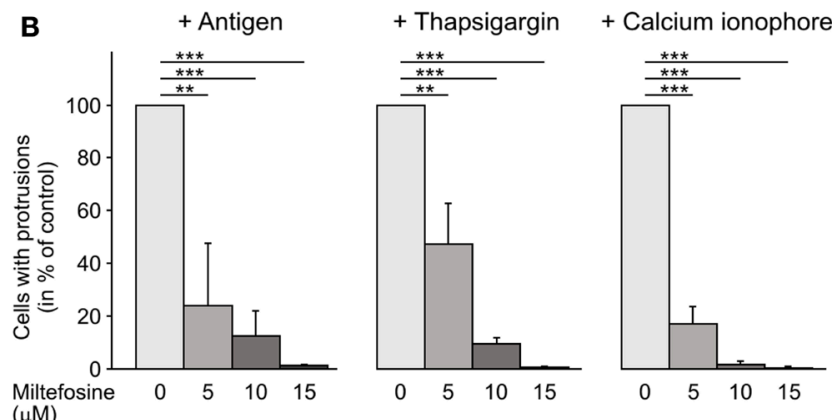

FIGURE 2 | Microtubule organization in activated bone marrow-derived mast cells (BMMCs) and Ag-induced chemotaxis are affected by miltefosine. (A) Microtubule organization. BMMCs incubated in the absence $(a, c, e)$ or presence (b,d,f) of $15 \mu \mathrm{M}$ miltefosine were activated by high affinity lgE receptor (FceRI) aggregation (a,b; antigen), thapsigargin (c,d) or calcium ionophore (e,f). Cells were fixed and stained for $\beta$-tubulin. Scale bars $10 \mu \mathrm{m}(\mathrm{a}, \mathrm{b})$, (c,d), and (e,f). (B) Quantitative analysis of the frequency of microtubule protrusions. BMMCs incubated with various concentrations of miltefosine $(5-15 \mu \mathrm{M})$ and BMMC controls were activated by FceRI aggregation (antigen), thapsigargin, or calcium ionophore. Values indicate mean $\pm \operatorname{SD}(n=3)$; ${ }^{\star *} p<0.01$ and ${ }^{* \star} p<0.001$. (C) Effect of miltefosine on the morphology of RPE1 cells. Cells incubated in the absence (a) or presence of 5 (b) and $15 \mu \mathrm{M}$ miltefosine (c) were fixed and stained for $\beta$-tubulin. Scale bars $10 \mu \mathrm{m}$. (D) Chemotaxis assay. Migration tracks in control cells and cells treated with $15 \mu \mathrm{M}$ miltefosine. Tracks from a representative experiment were aligned with their starting points at the coordinate position [0, 0]. Black tracks indicate individual cells with net migration toward the left chamber that contained Ag (100 ng/ml), red tracks indicate cells migrating in the opposite direction. Yellow crosses represent the average of endpoints. Representative experiments out of four repetitions are shown. (E) Cell migration. Migration velocities and accumulated distances of cells treated with $15 \mu \mathrm{M}$ miltefosine relative to the control cells. Data are mean $\pm \mathrm{SD}(n=5)$; ${ }^{*} p<0.05$.

We also evaluated whether miltefosine affects overall P-Tyr levels of Lyn and Syk kinases and LAT adaptor protein that are known to be involved in early stages of FceRI-mediated activation (1). P-Tyr levels were compared after immunoprecipitations from control and Ag-activated cells in the absence or presence of miltefosine. P-Tyr levels of Lyn kinase were comparable 

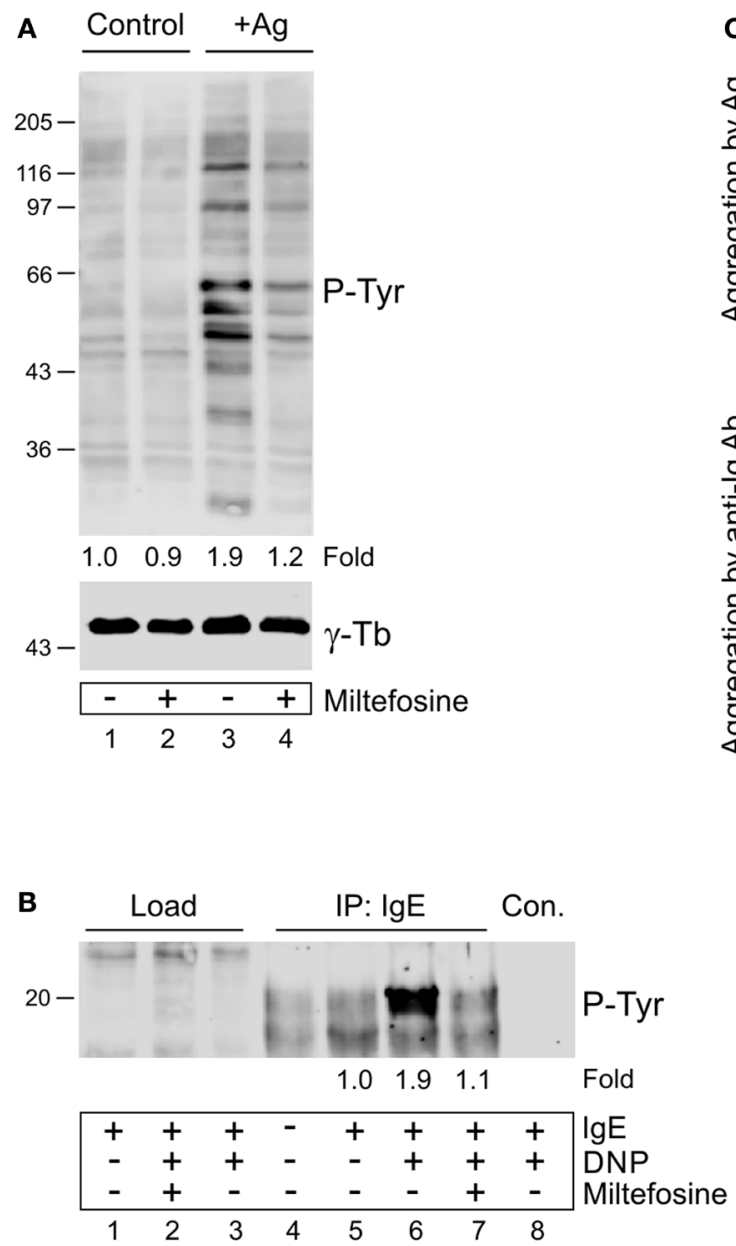
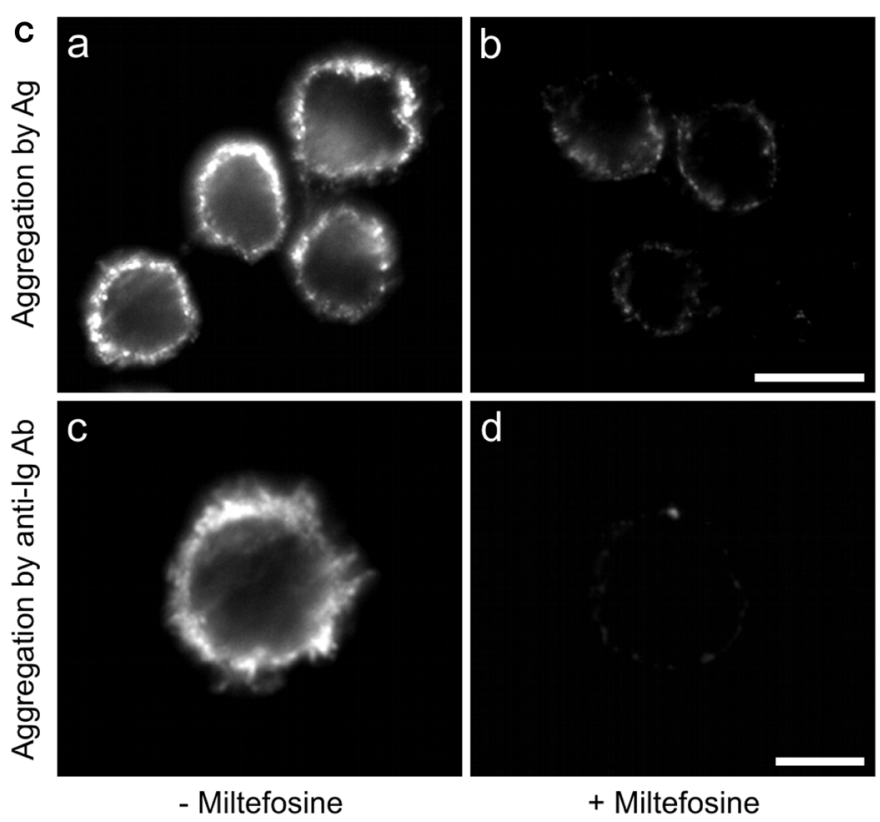

- Miltefosine

+ Miltefosine

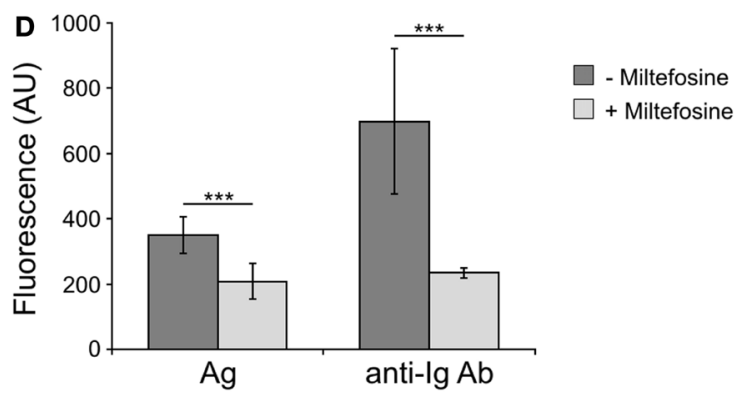

FIGURE 3 | Miltefosine affects tyrosine phosphorylation and aggregation of high affinity lgE receptors (FceRls) in activated bone marrow-derived mast cells (BMMCs). (A) Comparison of protein tyrosine phosphorylation level (P-Tyr) in control cells and cells activated by FceRl aggregation (+Ag) in the absence (lanes 1 and 3) or presence (lanes 2 and 4) of miltefosine. $\gamma$-Tubulin ( $\gamma$-Tb) served as a loading control. Representative image out of three repetitions is shown. Numbers under the blot indicate relative amounts of P-Tyr normalized to control cells and to the amount of $\gamma$-tubulin in individual samples (fold). (B) Comparison of FceRI receptor phosphorylation (P-Tyr) in the absence (lanes 1, 3-6, and 8) or presence (lanes 2 and 7) of miltefosine. Cells sensitized with mouse IgE to Ag were incubated with or without miltefosine, activated or not by $\mathrm{Ag}(\mathrm{DNP})$, and extracts were precipitated with anti-lgE Ab immobilized on protein A beads. In the control, protein A without $\mathrm{Ab}$ was incubated with the cell extract (lane 8, Con.). Note the difference in signal intensities in the positions of co-precipitated FceRI receptors when cells were incubated without (lane 6) or with (lane 7) miltefosine. Representative image out of three repetitions is shown. Numbers under the blot indicate relative amounts of P-Tyr normalized to sensitized cells (fold). (A,B) Bars on the left indicate positions of molecular weight markers in kDa. (C) Comparison of FCERI aggregation in the absence or presence of miltefosine. Cells sensitized with mouse lgE to Ag were incubated without (a,c) or with (b,d) miltefosine and activated by crosslinking of bound IgE with $\mathrm{Ag}$ (a,b; aggregation by Ag) or with anti-mouse lg Ab conjugated with DY549 (c,d; aggregation by anti-lg Ab). Cells were fixed with formaldehyde, and in the case of Ag-activated cells (a,b), stained with anti-mouse Ab conjugated with DY549. Images (a,b) and (c,d) were collected and processed under identical conditions. Scale bars, $10 \mu \mathrm{m}(\mathrm{a}, \mathrm{b}) ; 5 \mu \mathrm{m}$ (c,d). (D) Analysis of fluorescence intensity of FceRl aggregation in the absence or presence of miltefosine. BMMCs were activated by crosslinking of bound lgE with $\mathrm{Ag}(\mathrm{Ag})$ or with anti-mouse Ig Ab (anti-lg Ab). Values indicate mean $\pm \mathrm{SD}\left(\mathrm{Ag}, n=30 ;\right.$ anti-lg Ab, $n=5$ ); ${ }^{\star \star \star} p<0.001$.

both in non-activated and Ag-activated cells (Figure S2A in Supplementary Material, IP: Lyn, lanes 2-3), as reported previously (34), and were not affected by miltefosine (Figure S2A in Supplementary Material, IP: Lyn, lane 4). Ag-activation increased comparably the P-Tyr levels of Syk kinase both in the presence or absence of miltefosine (Figure S2A in Supplementary Material, IP: Syk, lanes 3-4). Finally, the P-Tyr level of LAT increased in Ag-activated cells and was slightly attenuated in miltefosinetreated cells (Figure S2A in Supplementary Material, IP: LAT, lanes 3-4). These data suggest that inhibition of aggregation and tyrosine phosphorylation of FceRI receptors by miltefosine does not substantially affect consecutive stages of signal transduction.

\section{Miltefosine Does Not Inhibit $\mathrm{Ca}^{2+}$ Influx in Activated BMMCs but Localizes to the Cellular Membranes and Cytosol}

We have reported that reorganization of microtubules in later stages of BMMC activation depends on $\mathrm{Ca}^{2+}$ influx (4). To test whether miltefosine affects the $\mathrm{Ca}^{2+}$ influx, we measured the 
level of intracellular $\mathrm{Ca}^{2+}$ after BMMC activation in control and miltefosine-treated cells (Figure 4A). Miltefosine did not inhibit the release of $\mathrm{Ca}^{2+}$ from the ER (data not shown) nor the influx of extracellular $\mathrm{Ca}^{2+}$ in cells activated with FceRI aggregation using Ag (Figure 4Aa). Miltefosine slightly increased the $\mathrm{Ca}^{2+}$ influx in thapsigargin-activated cells (Figure 4Ab), and this trend was also observed in cells activated by calcium ionophore (data not shown). In contrast, treatment with $10 \mathrm{mM} \mathrm{M} \beta C D$ inhibited
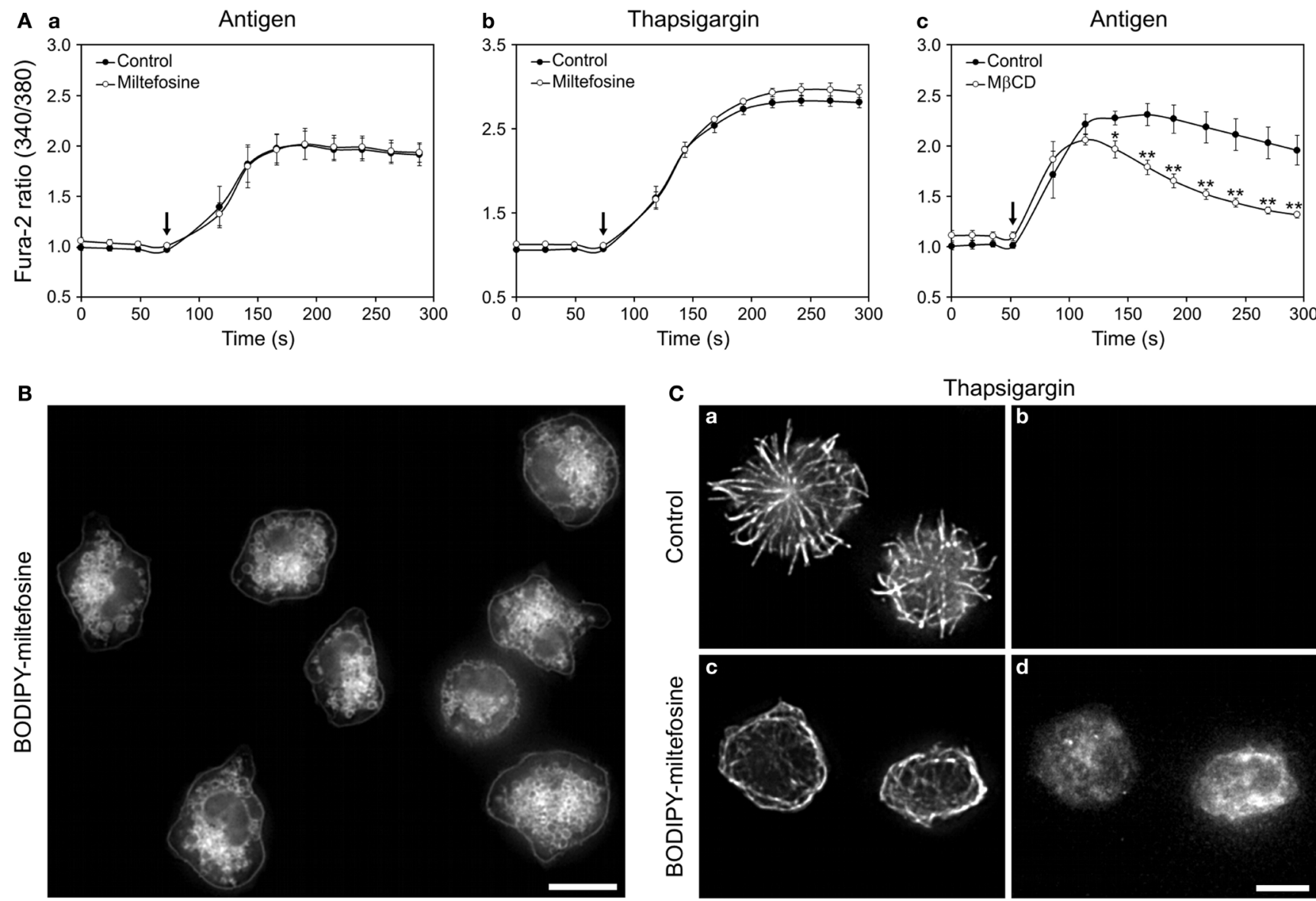

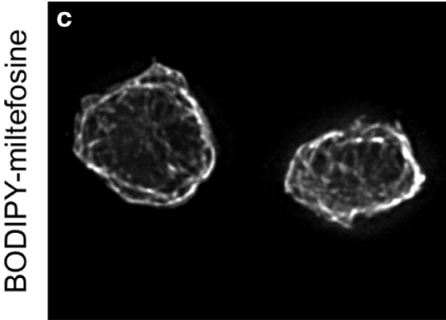

$\alpha$-tubulin

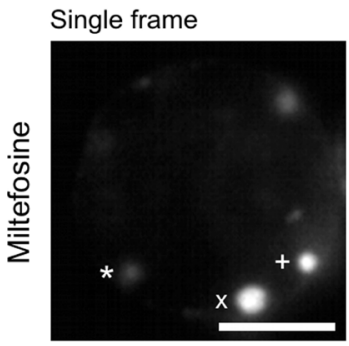

Kymograph

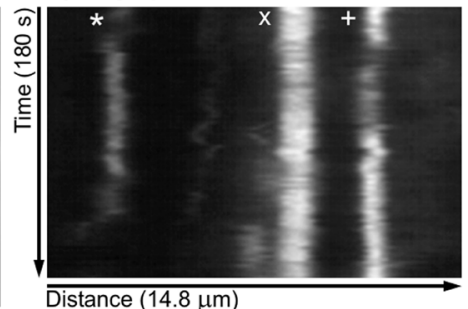

D Single frame

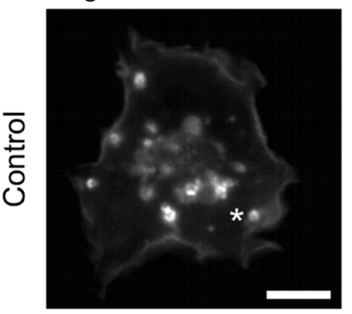

Kymograph

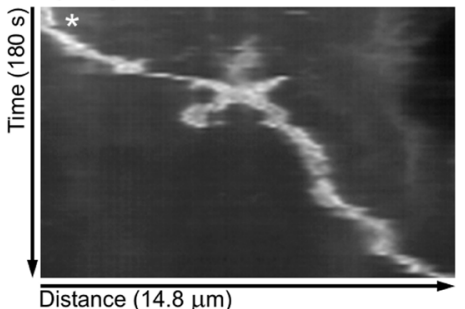

BODIPY . 
$\mathrm{Ca}^{2+}$ influx in Ag-activated BMMCs (Figure 4Ac). This points to the fact that these compounds, at concentrations causing similar inhibition of degranulation and formation of microtubule protrusions, have different effect on the signaling pathway leading to the $\mathrm{Ca}^{2+}$ influx in activated cells.

To evaluate the distribution of miltefosine in BMMCs we applied BODIPY-labeled miltefosine (28). Using this tool we localized it on the plasma membrane, intracellular membranous structures, as well as in the cytosol (Figure 4B). Internalization of BODIPY-miltefosine was rapid, as intracellular structures were decorated already after 1 min incubation with $15 \mu \mathrm{M}$ BODIPYmiltefosine. When the cells were incubated with $1 \mu \mathrm{M}$ BODIPYmiltefosine for 15-60 min, the intensity of staining increased in a time-dependent manner. BODIPY-miltefosine worked in the same way as the untagged miltefosine, as BODIPY-miltefosine inhibited generation of microtubule protrusions in cells activated with thapsigargin (Figure 4Cc,d; BODIPY-miltefosine), in contrast to control cells not treated with BODIPY-miltefosine (Figure 4Ca,b; control).

Secretory granules in living mast cells can be visualized by tagged WGA (5). Time-lapse imaging of BMMCs pre-treated with WGA-AF555 followed by kymograph analysis revealed that in comparison to control cells, $15 \mu \mathrm{M}$ miltefosine inhibited movements of some granules (Figure 4D). On the other hand, $10 \mathrm{mM}$ $\mathrm{M} \beta \mathrm{CD}$ did not affect the granule movement (data not shown).

These data show that although miltefosine inhibits aggregation and phosphorylation of FceRIs on the plasma membrane in activated cells, it does not inhibit the $\mathrm{Ca}^{2+}$ influx in activated cells. Moreover, miltefosine could affect signaling pathways in the cytosol as it rapidly localizes into the cell interior of BMMCs and influences granule movements.

\section{Miltefosine Inhibits $\mathrm{Ca}^{2+}$-Dependent PKCs in BMMCs}

It is well established that $\mathrm{Ca}^{2+}$ and diacylglycerol-regulated conventional PKCs (cPKCs) are important for mast cell degranulation (35). As miltefosine was reported to inhibit PKC in mouse $\mathrm{NIH} / 3 \mathrm{~T} 3$ cells (20), we evaluated the possibility that miltefosine could affect the activity of cPKCs in BMMCs. There are four isoforms of cPKCs, specifically, PKC $\alpha, P K C \beta I, P K C \beta I I$, and PKC $\gamma$ (36). The expression of $\mathrm{CPKCs}$ in BMMCs was determined by a gel-based RT-PCR analysis using mouse brain as a positive control. We found that PKC $\beta$ isoforms were the most prominent, while PKC $\gamma$ was under the detection limit (Figure 5A).

In vitro kinase assay revealed that miltefosine can inhibit the activities of cPKCs immunoprecipitated from BMMCs (Figure 5B left panel, lane 3). As a positive control we used Ly333531 inhibitor, which efficiently inhibited autophosphorylation of cPKCs immunoprecipitated from BMMCs (Figure 5B left panel, lane 4). Quantification of cPKC phosphorylation levels is shown in Figure 5B right panel. Ly333531 preferentially inhibits $\mathrm{PKC} \beta$ isoforms. The $\mathrm{IC}_{50}$ values for $\mathrm{PKC} \beta \mathrm{I}$ and $\mathrm{PKC} \beta \mathrm{II}$ are 4.7 and $5.9 \mathrm{nM}$, respectively, while for PKC $\eta,-\delta,-\gamma,-\alpha,-\varepsilon$, and $-\zeta$ are $0.052,0.25,0.30,0.36,0.6$, and $>100 \mu \mathrm{M}$, respectively (37). As $\mathrm{PKC} \beta$ isoforms were the most abundant in BMMCs, we examined the effect of Ly333531 on degranulation, generation of microtubule protrusions, $\mathrm{Ca}^{2+}$ influx, and cell migration.
Ly333531, similarly as miltefosine, significantly inhibited $\beta$ hexosaminidase release in a dose-dependent manner in cells activated by FceRI aggregation (Figure 5C, antigen), thapsigargin (Figure 5C), or pervanadate (data not shown). Generation of microtubule protrusions was attenuated by Ly333531 treatment in BMMCs activated by Ag or thapsigargin (Figure 5D). Statistical evaluation of this effect is shown in Figure 5E. While Ly333531 did not affect the $\mathrm{Ca}^{2+}$ influx (Figure 5F), cell motility was inhibited by its treatment (Figure 5G). Collectively, these data demonstrate that cPKC inhibitor Ly333531 modulates mast cell functions in the same way as miltefosine. This suggests that miltefosine might regulate these processes through the inhibition of cPKC activity.

\section{DISCUSSION}

Mast cell activation by crosslinking of FceRIs triggers the signaling pathways resulting in $\mathrm{Ca}^{2+}$ influx, degranulation, and synthesis of new mediators. Pharmaceutical agents that modulate integrity of the membrane environment or affect mast cell signaling events might be potentially used as treatments for mast cell-driven diseases. A promising candidate is the lipid raft modulator miltefosine (15). The obvious advantages of miltefosine are known side effects, which are relatively safe, dose-dependent, and reversible (38). Clinical application has been limited to topical and oral treatments, and among major known side effects belong loss of appetite, vomiting, nausea, and diarrhea after long oral treatment of high daily dosages (150 mg and higher) (39). Although miltefosine was approved for the treatment of various diseases (40), the molecular mechanism of its action in mast cells remains poorly understood.

In human skin mast cells, it has been suggested that miltefosine affects organization of FceRIs in the plasma membrane, which then leads to modulation of subsequent activation steps $(7,15)$. Here we used murine BMMCs as they are well responsive to both allergic and non-allergic stimuli and they are generally used for in vitro studies, as they can be easily produced in large amounts (41). Different murine mast cell types, specifically connective tissue mast cells (CTMCs), mucosal tissue mast cells (MMCs), and BMMCs, all express c-kit and FceRIs on their surfaces, and can degranulate upon Ag-activation (42). CTMCs and BMMCs differ in TLR (toll-like receptor)-induced cytokine and chemokine production, expression of STAT proteins, and response to IL18 (42, 43). However, such differences should not have effect on early signaling events after FceRI aggregation in these cells. Molecular mechanisms of miltefosine action in early stages of Agactivation could be, therefore, similar both in BMMCs and CTMCs (e.g., human skin mast cells).

Our results demonstrate that BMMCs have similar sensitivity to miltefosine as human mast cells (7) and that $15 \mu \mathrm{M}$ miltefosine does not change cell viability. Degranulation was attenuated in miltefosine-treated cells in a dose-dependent manner after cell activation by FceRI aggregation, thapsigargin, pervanadate, or calcium ionophore. Obtained data were comparable to the mediator release of miltefosine-treated human primary mast cells activated by $\mathrm{Ag}$ (7). We have previously shown that activation of BMMCs leads to rapid cytoskeleton rearrangement and generation of microtubule protrusions (4). Here, we demonstrate that 
in activated BMMCs, miltefosine suppresses formation of these protrusions and affects cell morphology more effectively than in other tested cell types. As miltefosine inhibited formation of protrusions containing microtubules more effectively than degranulation, we suppose that physical integration of miltefosine into the plasma membrane contributes to this effect. Moreover, miltefosine also inhibits chemotaxis to $\mathrm{Ag}$ and cell motility, which points to a limited capability of miltefosine-treated cells to accumulate in the site of disease manifestation. These data indicate that miltefosine could modulate physiology of mast cells at different levels.

To get deeper insight into the effect(s) of miltefosine in mast cells, we evaluated early steps of cell activation after aggregation of FceRIs by Ag. Miltefosine inhibited both the overall tyrosine phosphorylation level and the aggregation and tyrosine phosphorylation of FceRIs. Diminished FceRIs phosphorylation could be due to the changes in plasma membrane properties that inhibit formation of large FceRI aggregates. Protein tyrosine kinase Lyn
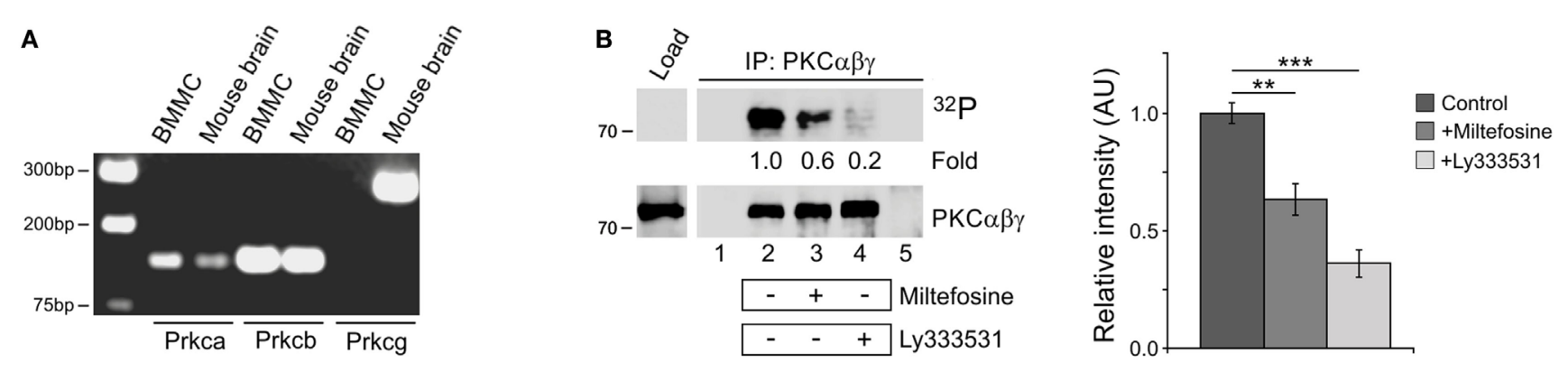

c
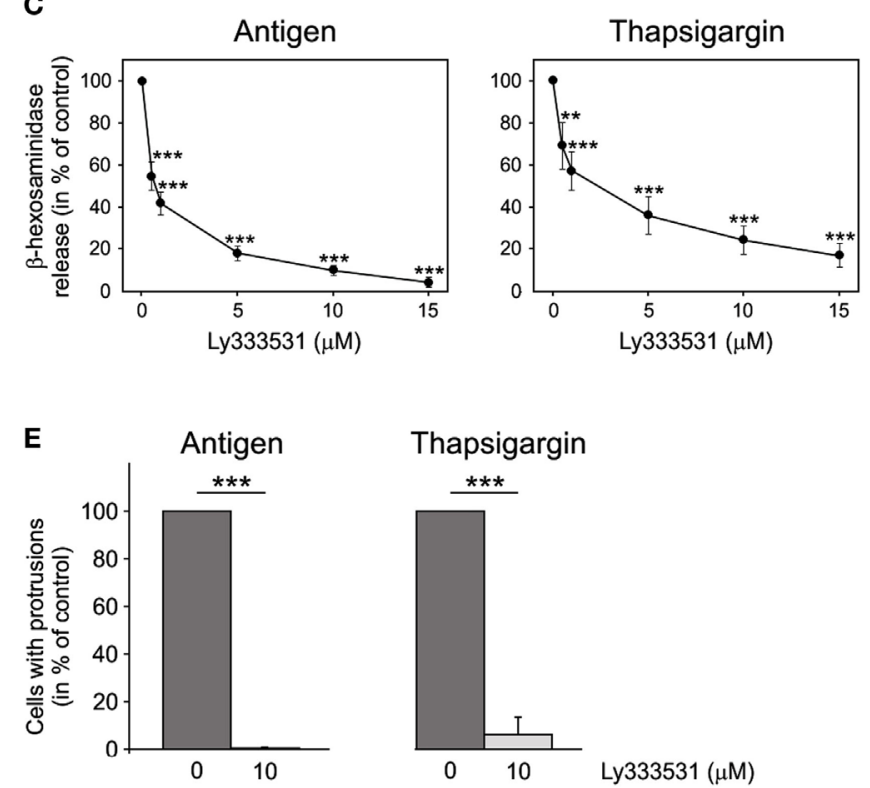

$\mathbf{F}$
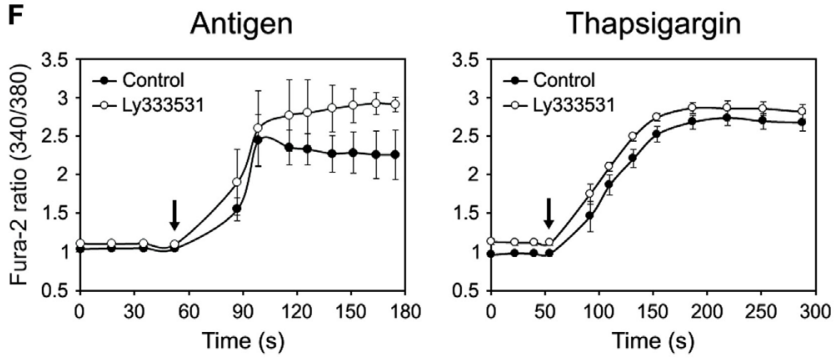

D
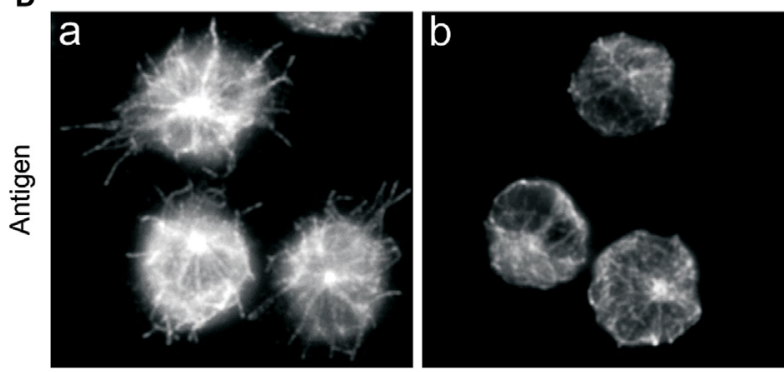

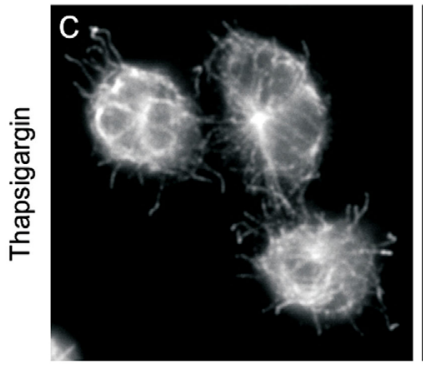

- Ly333531

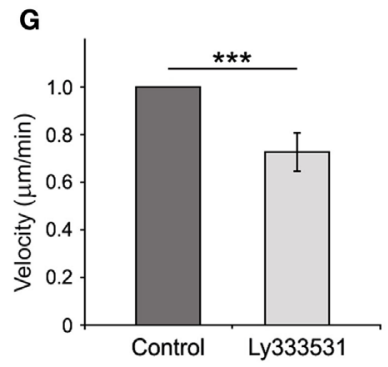

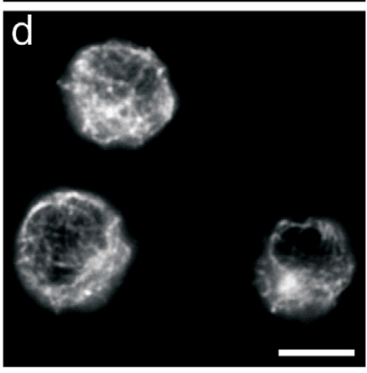

+ Ly333531

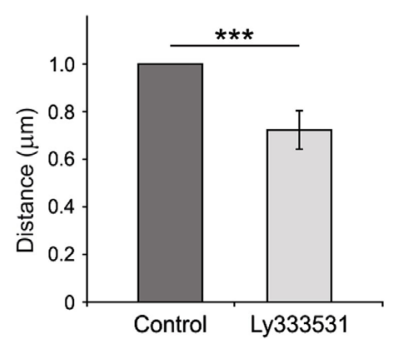

FIGURE 5 | Continued 
FIGURE 5 | Miltefosine inhibits conventional protein kinase C (CPKC) activity in bone marrow-derived mast cells (BMMCs), and specific cPKC inhibitor Ly333531 affects degranulation, generation of microtubule protrusions, $\mathrm{Ca}^{2+}$-influx, and cell motility in a similar way as miltefosine. (A) Expression profile of cPKCs in BMMCs. Gel-based RT-PCR analysis of mouse PKC $\alpha$ (Prkca), PKC $\beta$ (Prkcb), and PKC $\gamma$ (Prkcg). Mouse brain served as positive control. (B) The kinase activity in PKC $\alpha \beta \gamma$ immunocomplexes is inhibited by miltefosine. BMMC lysates were precipitated with anti-PKC $\alpha \beta \gamma$ Ab bound to protein A carrier. Immunocomplexes were subjected to in vitro kinase assay, electrophoretically separated, and detected by autoradiography $\left.{ }^{32} \mathrm{P}\right)$. The presence of PKC $\alpha \beta \gamma$ in immunocomplexes was confirmed by immunoblotting with anti-PKC $\alpha \beta \gamma$ Ab. (Left panel) Precipitation from resting cells (lane 2), cells pre-treated with $15 \mu \mathrm{M}$ miltefosine (lane 3), and cells pre-treated with

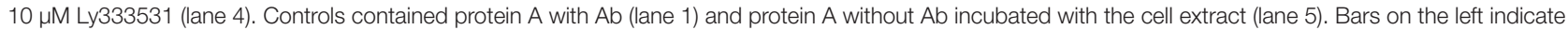
positions of molecular weight markers in $\mathrm{kDa}$. Representative image out of three repetitions is shown. Numbers under the blot indicate relative amounts of phosphorylated cPKCs normalized to control cells and to the amount of precipitated cPKCs in individual samples (fold). (Right panel) Quantification of autoradiographs by densitometry. Control untreated cells or cells pre-treated with $15 \mu \mathrm{M}$ miltefosine (+miltefosine) or $10 \mu \mathrm{M}$ Ly333531 (+Ly333531). Relative intensities of phosphorylated CPKCs normalized to control cells and to the amount of precipitated CPKCs in individual samples. Data represent mean \pm SD $(n=3)$; ${ }^{* *} p<0.01$ and ${ }^{* * *} p<0.001$. (C) $C P K C$ s are essential for BMMC degranulation. BMMCs pre-incubated with different concentrations of Ly333531 (0.5-15 $\left.\mu M\right)$ were activated by Ag or thapsigargin and degranulation was measured by $\beta$-hexosaminidase release. Values represent mean $\pm \operatorname{SD}(n=4)$; ${ }^{* *} p<0.01$ and ${ }^{* \star *} p<0.001$. (D) CPKCs regulate microtubule organization. BMMCs incubated in the absence $(a, c)$ or presence $(b, d)$ of $10 \mu \mathrm{M}$ Ly333531 were activated by high affinity lgE receptor (FcERI) aggregation (a-b; antigen) or thapsigargin (c-d). Cells were fixed and stained for $\beta$-tubulin. Scale bar $10 \mu m(a-d)$. (E) Quantitative analysis of the

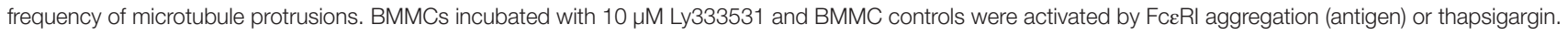
Values indicate mean $\pm \mathrm{SD}(n=3) ;{ }^{* \star *} p<0.001$. (F) CPKCs do not inhibit Ca ${ }^{2+}$ influx in activated BMMCs. Sensitized cells were loaded with Fura-2-acetoxymethyl ester, pre-treated without (control) or with $10 \mu \mathrm{M} \mathrm{Ly} 333531$, and activated by Ag or thapsigargin. Arrows indicate addition of Ag or thapsigargin. Data represent mean $\pm \mathrm{SE}$ ( $n=2$ for Ag; $n=3$ for thapsigargin) of independent experiments performed in duplicates. (G) Cell migration depends on cPKCs. Migration velocities and accumulated distances of cells treated with $10 \mu \mathrm{M}$ Ly333531 relative to the control cells. Data are mean $\pm \mathrm{SD}(n=3) ;{ }^{* \star *} p<0.001$

can, therefore, only partially phosphorylate both ITAMs, located on the cytoplasmic tails of FceRI $\beta$ and $\gamma$ subunits (33). Our data thus support the previous suggestion that miltefosine attenuates FceRI-mediated signaling events at the plasma membrane $(7,15)$.

Miltefosine treatment, however, did not affect overall P-Tyr levels of Lyn and Syk kinases and only slightly diminished P-Tyr level of adaptor protein LAT in Ag-activated cells. Moreover, miltefosine did not inhibit the release of $\mathrm{Ca}^{2+}$ from ER nor the extracellular $\mathrm{Ca}^{2+}$ influx. This indicates that the low level of FceRI phosphorylation observed after cell activation in the presence of miltefosine is sufficient to activate the subsequent signaling cascade. It was reported previously that the formation of large FceRI aggregates is not necessary for triggering the signaling responses, and that Ag-activated mast cells propagate signals from small signaling domains formed around dimerized FceRIs (44). Moreover, it is well established that cholesterol-dependent ordered lipids regulate the $\mathrm{Ca}^{2+}$ channel (Orai1), and polyunsaturated fatty acids with phosphoinositides regulate coupling of Orail to ER $\mathrm{Ca}^{2+}$ sensor (STIM1) in SOCE (45). Our results suggest that although miltefosine affects the membrane composition and aggregation of FceRI receptors, this is not reflected in the inhibition of the $\mathrm{Ca}^{2+}$ influx level through SOCE.

Calcium mobilization has a critical impact on activation of many signal-transducing proteins that are involved in the regulation of mast cell degranulation. We observed differential miltefosine inhibitory effects on degranulation in BMMCs activated by Ag, thapsigargin, pervanadate, or calcium ionophore. This probably reflects the specificity and site(s) of action of the used activators. When miltefosine was compared with $\mathrm{M} \beta \mathrm{CD}$, a typical lipid raft disruptor, $\mathrm{M} \beta \mathrm{CD}$ had to be used at $~ 1,000$-fold higher concentrations to inhibit degranulation, microtubule rearrangement, and cell motility to the levels observed in miltefosine-treated cells. Moreover, $\mathrm{M} \beta \mathrm{CD}$ effectively inhibited $\mathrm{Ca}^{2+}$ influx in activated BMMCs. The fact that miltefosine does not inhibit the $\mathrm{Ca}^{2+}$ influx indicates that it could attenuate degranulation by affecting the cytosolic signaling pathway(s) after SOCE. It is well established that $\mathrm{Ca}^{2+}$-dependent PKCs are important for mast cell degranulation (35). In BMMCs, we detected PKC $\alpha$ and PKC $\beta$ isoforms, and their activities were inhibited by miltefosine. Similarly as miltefosine, cPKC inhibitor Ly333531 inhibited mast cell degranulation, generation of microtubule protrusions and cell migration, while $\mathrm{Ca}^{2+}$ influx was not affected. At present, there is a search for new compounds that inhibit PKCs. It has been proposed that drugs modulating the activity of PKCs could have a major impact on the treatment of immune disorders (46). Deciphering the exact mechanism of PKC inhibition by miltefosine warrants further investigation.

In BMMCs, miltefosine localized to the plasma membrane, cytosol, and intracellular membranous structures including granules. Staining of intracellular structures with BODIPY-miltefosine was previously shown in Leishmania donovani at $7 \mu \mathrm{M}$ concentration for $4 \mathrm{~h}$ (28). Here, we show that internalization of BODIPYmiltefosine in BMMCs is fast and even at $1 \mu \mathrm{M}$ concentration it incorporates to intracellular membranous structures within $15 \mathrm{~min}$. Moreover, cytosolic miltefosine attenuated movement of some intracellular BMMC granules.

It was reported that miltefosine inhibits PI3K/Akt survival pathway in tumor (17) and skeletal muscle cells (47). As PI3K/Akt pathway is important for survival, growth, and differentiation in activated mast cells (48), miltefosine might affect also these activities. It is known that Akt is partially activated by phosphorylation at $\mathrm{Thr}^{308}$ through PI3K/PDK1 (3-phosphoinositide-dependent protein kinase 1) pathway and fully activated by additional phosphorylation at $\mathrm{Ser}^{473}$ through PI3K/mTORC2 (mechanistic target of rapamycin complex 2) pathway (49). We have found that miltefosine in Ag-activated BMMCs inhibited phosphorylation on both $\mathrm{Thr}^{308}$ and Ser ${ }^{473}$ (Figure S2B in Supplementary Material, lanes 2-3). As miltefosine enters to cytosol, it could affect Aktdependent cellular activities that will manifest in later stages of mast cell activation.

Effective treatments of mast cell-derived mastocytosis (8), urticaria (9), and atopic dermatitis (10) were after topical application of miltefosine. On the other hand, miltefosine side effects in gastrointestinal tract were observed after oral use in cancer patients. We do not assume that these side effects could be explained 
by inhibition of degranulation by miltefosine, as vomiting and diarrhea are connected with increased number of degranulating mast cells in digestive tract (50). PKCs are central kinases and their inhibition by miltefosine could also affect other cell types. However, sensitivity of cells to miltefosine can substantially differ as we documented on changes in microtubule organization in BMMCs or RPE1 and U2OS cells.

Based on the published data and findings in this report, we suggest that miltefosine might affect mast cell activation by different mechanisms. First, incorporation of miltefosine into the plasma membrane influences its properties. This results in morphological changes, inhibition of FceRI aggregation by Ag, chemotaxis, and generation of microtubule protrusions in the course of specific (Ag) or unspecific (thapsigargin, pervanadate, and calcium ionophore) activation. Second, as miltefosine does not inhibit $\mathrm{Ca}^{2+}$ response and rapidly enters into the cytosol, it is able to modulate the intracellular signaling pathways important for degranulation. Upon cell activation, $\mathrm{Ca}^{2+}$ and PKCs act to reverse the inhibitory mechanisms of granule fusion and activate proteins and cellular events to promote the granule fusion (51). Because miltefosine inhibits $\mathrm{Ca}^{2+}$-dependent cPKCs, it could interfere with this pathway. Third, miltefosine attenuates movements of intracellular granules. It could, therefore, affect the function of microtubule motors that are important for transport of secretory granules in mast cells (5).

In conclusion, our data suggest that miltefosine modulates BMMCs both at the plasma membrane and in the cytosol by an inhibition of $\mathrm{Ca}^{2+}$-dependent PKCs. This leads to substantial morphological changes, inhibition of chemotaxis and degranulation. Effective treatment of mast cell-derived diseases by miltefosine could be, therefore, based on its action at multiple sites in the cells.

\section{DATA AVAILABILITY STATEMENT}

The raw data supporting the conclusions of this manuscript will be made available by the authors, without undue reservation, to any qualified researcher.

\section{REFERENCES}

1. Draber P, Halova I, Polakovicova I, Kawakami T. Signal transduction and chemotaxis in mast cells. Eur J Pharmacol (2016) 778:11-23. doi:10.1016/j. ejphar.2015.02.057

2. Nishida K, Yamasaki S, Ito Y, Kabu K, Hattori K, Tezuka T, et al. FceRImediated mast cell degranulation requires calcium-independent microtubuledependent translocation of granules to the plasma membrane. J Cell Biol (2005) 170:115-26. doi:10.1083/jcb.200501111

3. Sulimenko V, Dráberová E, Sulimenko T, Macůrek L, Richterová V, Dráber P, et al. Regulation of microtubule formation in activated mast cells by complexes of $\gamma$-tubulin with Fyn and Syk kinases. J Immunol (2006) 176:7243-53. doi:10.4049/jimmunol.176.12.7243

4. Hájková Z, Bugajev V, Dráberová E, Vinopal S, Dráberová L, Janáček J, et al. STIM1-directed reorganization of microtubules in activated mast cells. J Immunol (2011) 186:913-23. doi:10.4049/jimmunol.1002074

5. Munoz I, Danelli L, Claver J, Goudin N, Kurowska M, Madera-Salcedo IK, et al. Kinesin-1 controls mast cell degranulation and anaphylaxis through PI3K-dependent recruitment to the granular Slp3/Rab27b complex. J Cell Biol (2016) 215:203-16. doi:10.1083/jcb.201605073

6. Pressman BC. Biological applications of ionophores. Annu Rev Biochem (1976) 45:501-30. doi:10.1146/annurev.bi.45.070176.002441

7. Weller K, Artuc M, Jennings G, Friedrichson T, Guhl S, dos Santos RV, et al. Miltefosine inhibits human mast cell activation and mediator release

\section{AUTHOR CONTRIBUTIONS}

ZR designed, performed and analyzed microscopic experiments, and prepared the manuscript. VS performed immunoprecipitation and kinase assays. TP performed intracellular $\mathrm{Ca}^{2+}$ measurements and PD planned the experiments, helped with result interpretation, and revised the manuscript. All authors approved the final version of the manuscript.

\section{ACKNOWLEDGMENTS}

We thank V. Sládková for RT-PCR experiments, T. Sulimenko for immunoprecipitation experiments, and I. Mlchová for excellent technical assistance. We also thank Dr. A. U. Acuña (Instituto de Química-Física, CSIC, Madrid, Spain) for BODIPY-labeled miltefosine (MT-11c-6EtBDPY), Dr. M. Bonhivers (Université Bordeaux, Bordeaux, France) for the gift of RPE1 cells, Dr. Petr Dráber (IMG CAS, Prague) for rabbit polyclonal Ab to mouse IgE, and Dr. M. Hibbs (Ludwig Institute for Cancer Research, Melbourne, Australia) for BMMC cells.

\section{FUNDING}

This work was supported in part by grant LD13015 for COST actions BM1007 from the Ministry of Education, Youth and Sports of the Czech Republic, grants 15-22194S, 16-25159S, 16-23702S, and 17-20915S from the Grant Agency of the Czech Republic and by Institutional Research Support (RVO 68378050).

\section{SUPPLEMENTARY MATERIAL}

The Supplementary Material for this article can be found online at https://www.frontiersin.org/articles/10.3389/fimmu.2018.01563/ full\#supplementary-material.

both in vitro and in vivo. J Invest Dermatol (2009) 129:496-8. doi:10.1038/ jid.2009.134

8. Hartmann K, Siebenhaar F, Belloni B, Brockow K, Eben R, Hartmann B, et al. Effects of topical treatment with the raft modulator miltefosine and clobetasol in cutaneous mastocytosis: a randomized, double-blind, placebocontrolled trial. Br J Dermatol (2010) 162:185-90. doi:10.1111/j.1365-2133. 2009.09434.x

9. Magerl M, Rother M, Bieber T, Biedermann T, Brasch J, Dominicus R, et al. Randomized, double-blind, placebo-controlled study of safety and efficacy of miltefosine in antihistamine-resistant chronic spontaneous urticaria. J Eur Acad Dermatol Venereol (2013) 27:363-9. doi:10.1111/j.1468-3083.2012.04689.x

10. Dölle S, Hoser D, Rasche C, Loddenkemper C, Maurer M, Zuberbier T, et al. Long-term reduction in local inflammation by a lipid raft molecule in atopic dermatitis. Allergy (2010) 65:1158-65. doi:10.1111/j.1398-9995.2010.02341.x

11. Monge-Maillo B, López-Vélez R. Miltefosine for visceral and cutaneous leishmaniasis: drug characteristics and evidence-based treatment recommendations. Clin Infect Dis (2015) 60:1398-404. doi:10.1093/cid/civ004

12. Schuster FL, Guglielmo BJ, Visvesvara GS. In-vitro activity of miltefosine and voriconazole on clinical isolates of free-living amebas: Balamuthia mandrillaris, Acanthamoeba spp., and Naegleria fowleri. J Eukaryot Microbiol (2006) 53:121-6. doi:10.1111/j.1550-7408.2005.00082.x

13. Barratt G, Saint-Pierre-Chazalet M, Loiseau PM. Cellular transport and lipid interactions of miltefosine. Curr Drug Metab (2009) 10:247-55. doi:10.2174/ 138920009787846332 
14. van der Luit AH, Vink SR, Klarenbeek JB, Perrissoud D, Solary E, Verheij M, et al. A new class of anticancer alkylphospholipids uses lipid rafts as membrane gateways to induce apoptosis in lymphoma cells. Mol Cancer Ther (2007) 6:2337-45. doi:10.1158/1535-7163.MCT-07-0202

15. Maurer M, Magerl M, Metz M, Weller K, Siebenhaar F. Miltefosine: a novel treatment option for mast cell-mediated diseases. J Dermatolog Treat (2013) 24:244-9. doi:10.3109/09546634.2012.671909

16. van Blitterswijk WJ, Verheij M. Anticancer alkylphospholipids: mechanisms of action, cellular sensitivity and resistance, and clinical prospects. Curr Pharm Des (2008) 14:2061-74. doi:10.2174/138161208785294636

17. Ruiter GA, Zerp SF, Bartelink H, van Blitterswijk WJ, Verheij M. Anti-cancer alkyl-lysophospholipids inhibit the phosphatidylinositol 3-kinase-Akt/PKB survival pathway. Anticancer Drugs (2003) 14:167-73. doi:10.1097/00001813200302000-00011

18. Ward PD, Ouyang H, Thakker DR. Role of phospholipase C- $\beta$ in the modulation of epithelial tight junction permeability. J Pharmacol Exp Ther (2003) 304:689-98. doi:10.1124/jpet.102.043638

19. Lucas L, Hernández-Alcoceba R, Penalva V, Lacal JC. Modulation of phospholipase D by hexadecylphosphorylcholine: a putative novel mechanism for its antitumoral activity. Oncogene (2001) 20:1110-7. doi:10.1038/sj.onc.1204216

20. Überall F, Oberhuber H, Maly K, Zaknun J, Demuth L, Grunicke HH. Hexadecylphosphocholine inhibits inositol phosphate formation and protein kinase C activity. Cancer Res (1991) 51:807-12.

21. Kovářová $\mathrm{M}$, Tolar $\mathrm{P}$, Arudchandran $\mathrm{R}$, Dráberová L, Rivera J, Dráber $\mathrm{P}$. Structure-function analysis of Lyn kinase association with lipid rafts and initiation of early signaling events after Fce receptor I aggregation. Mol Cell Biol (2001) 21:8318-28. doi:10.1128/MCB.21.24.8318-8328.2001

22. Tolar $\mathrm{P}$, Tůmová $\mathrm{M}$, Dráber $\mathrm{P}$. New monoclonal antibodies recognizing the adaptor protein LAT. Folia Biol (Praha) (2001) 47:215-7.

23. Volná $\mathrm{P}$, Lebduška $\mathrm{P}$, Dráberová L, Šímová $\mathrm{S}$, Heneberg $\mathrm{P}$, Boubelík M, et al. Negative regulation of mast cell signaling and function by the adaptor LAB/ NTAL. J Exp Med (2004) 200:1001-13. doi:10.1084/jem.20041213

24. Nováková M, Dráberová E, Schürmann W, Czihak G, Viklický V, Dráber P. $\gamma$-Tubulin redistribution in taxol-treated mitotic cells probed by monoclonal antibodies. Cell Motil Cytoskeleton (1996) 33:38-51. doi:10.1002/ (SICI)1097-0169(1996)33:1<38::AID-CM5>3.0.CO;2-E

25. Hibbs ML, Tarlinton DM, Armes J, Grail D, Hodgson G, Maglitto R, et al. Multiple defects in the immune system of Lyn-deficient mice, culminating in autoimmune disease. Cell (1995) 83:301-11. doi:10.1016/0092-8674(95)90171-X

26. Heneberg P, Lebduška P, Dráberová L, Korb J, Dráber P. Topography of plasma membrane microdomains and its consequences for mast cell signaling. Eur J Immunol (2006) 36:2795-806. doi:10.1002/eji.200636159

27. Černohorská M, Sulimenko V, Hájková Z, Sulimenko T, Sládková V, Vinopal S,

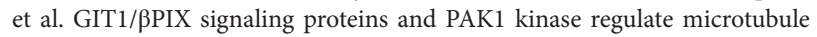
nucleation. Biochim Biophys Acta (2016) 1863:1282-97. doi:10.1016/j. bbamcr.2016.03.016

28. Hornillos V, Carrillo E, Rivas L, Amat-Guerri F, Acuña AU. Synthesis of BODIPY-labeled alkylphosphocholines with leishmanicidal activity, as fluorescent analogues of miltefosine. Bioorg Med Chem Lett (2008) 18:6336-9. doi:10.1016/j.bmcl.2008.10.089

29. Dráberová E, Sulimenko V, Vinopal S, Sulimenko T, Sládková V, D’Agostino L, et al. Differential expression of human $\gamma$-tubulin isotypes during neuronal development and oxidative stress points to a $\gamma$-tubulin-2 prosurvival function. FASEB J (2017) 31:1828-46. doi:10.1096/fj.201600846RR

30. Sulimenko V, Sulimenko T, Poznanovic S, Nechiporuk-Zloy V, Böhm KJ, Macurek L, et al. Association of brain $\gamma$-tubulins with $\alpha \beta$-tubulin dimers. Biochem J (2002) 365:889-95. doi:10.1042/bj20020175

31. Bambousková M, Hájková Z, Dráber P, Dráber P. Microscopy assays for evaluation of mast cell migration and chemotaxis. Methods Mol Biol (2014) 1192:161-76. doi:10.1007/978-1-4939-1173-8_12

32. Dráberová E, Dráber P. A microtubule-interacting protein involved in coalignment of vimentin intermediate filaments with microtubules. J Cell Sci (1993) 106:1263-73.

33. Kinet JP. The high-affinity IgE receptor (FceRI): from physiology to pathology. Annu Rev Immunol (1999) 17:931-72. doi:10.1146/annurev.immunol.17.1.931

34. Surviladze Z, Dráberová L, Kovářová M, Boubelík M, Dráber P. Differential sensitivity to acute cholesterol lowering of activation mediated via the high-affinity IgE receptor and Thy-1 glycoprotein. Eur J Immunol (2001) 31:1-10. doi:10.1002/1521-4141(200101)31:1<1::AID-IMMU1>3.0.CO;2-W

35. Yanase Y, Hide I, Mihara S, Shirai Y, Saito N, Nakata Y, et al. A critical role of conventional protein kinase $\mathrm{C}$ in morphological changes of rodent mast cells. Immunol Cell Biol (2011) 89:149-59. doi:10.1038/icb.2010.67

36. Lim PS, Sutton CR, Rao S. Protein kinase C in the immune system: from signalling to chromatin regulation. Immunology (2015) 146:508-22. doi:10.1111/ imm. 12510

37. Faul MM, Gillig JR, Jirousek MR, Ballas LM, Schotten T, Kahl A, et al. Acyclic N-(azacycloalkyl)bisindolylmaleimides: isozyme selective inhibitors of PKC $\beta$. Bioorg Med Chem Lett (2003) 13:1857-9. doi:10.1016/S0960-894X (03)00286-5

38. Verhaar AP, Wildenberg ME, Peppelenbosch MP, Hommes DW, van den Brink GR. Repurposing miltefosine for the treatment of immune-mediated disease? J Pharmacol Exp Ther (2014) 350:189-95. doi:10.1124/jpet.113.212654

39. Verweij J, Planting A, van der Burg M, Stoter G. A dose-finding study of miltefosine (hexadecylphosphocholine) in patients with metastatic solid tumours. J Cancer Res Clin Oncol (1992) 118:606-8. doi:10.1007/BF01211805

40. Pachioni Jde A, Magalhães JG, Lima EJ, Bueno Lde M, Barbosa JF, de Sá MM, et al. Alkylphospholipids - a promising class of chemotherapeutic agents with a broad pharmacological spectrum. J Pharm Pharm Sci (2013) 16:742-59. doi:10.18433/J3CW23

41. Vukman KV, Metz M, Maurer M, O’Neill SM. Isolation and culture of bone marrow-derived mast cells. Bio-Protocol (2014) 4:e1053. doi:10.21769/ BioProtoc. 1053

42. Ruschmann J, Antignano F, Lam V, Snyder K, Kim C, Essak M, et al. The role of SHIP in the development and activation of mouse mucosal and connective tissue mast cells. J Immunol (2012) 188:3839-50. doi:10.4049/jimmunol. 1003875

43. Matsushima H, Yamada N, Matsue H, Shimada S. TLR3-, TLR7-, and TLR9mediated production of proinflammatory cytokines and chemokines from murine connective tissue type skin-derived mast cells but not from bone marrow-derived mast cells. J Immunol (2004) 173:531-41. doi:10.4049/ jimmunol.173.1.531

44. Dráberová L, Lebduška $\mathrm{P}$, Hálová I, Tolar $\mathrm{P}$, Štokrová J, Tolarová $\mathrm{H}$, et al. Signaling assemblies formed in mast cells activated via Fce receptor I dimers. Eur J Immunol (2004) 34:2209-19. doi:10.1002/eji.200322663

45. Holowka D, Baird B. Roles for lipid heterogeneity in immunoreceptor signaling. Biochim Biophys Acta (2016) 1861:830-6. doi:10.1016/j.bbalip.2016. 03.019

46. Altman A, Kong KF. Protein kinase C inhibitors for immune disorders. Drug Discov Today (2014) 19:1217-21. doi:10.1016/j.drudis.2014.05.008

47. Verma NK, Dey CS. The anti-leishmanial drug miltefosine causes insulin resistance in skeletal muscle cells in vitro. Diabetologia (2006) 49:1656-60. doi:10.1007/s00125-006-0260-1

48. Kim MS, Rådinger M, Gilfillan AM. The multiple roles of phosphoinositide 3-kinase in mast cell biology. Trends Immunol (2008) 29:493-501. doi:10.1016/ j.it.2008.07.004

49. Linke M, Fritsch SD, Sukhbaatar N, Hengstschläger M, Weichhart T. mTORC1 and mTORC2 as regulators of cell metabolism in immunity. FEBS Lett (2017) 591:3089-103. doi:10.1002/1873-3468.12711

50. Ramsay DB, Stephen S, Borum M, Voltaggio L, Doman DB. Mast cells in gastrointestinal disease. Gastroenterol Hepatol (N Y) (2010) 6:772-7.

51. Blank U, Rivera J. The ins and outs of IgE-dependent mast-cell exocytosis. Trends Immunol (2004) 25:266-73. doi:10.1016/j.it.2004.03.005

Conflict of Interest Statement: The authors declare that the research was conducted in the absence of any commercial or financial relationships that could be construed as a potential conflict of interest.

Copyright (c) 2018 Rubíková, Sulimenko, Paulenda and Dráber. This is an openaccess article distributed under the terms of the Creative Commons Attribution License (CC BY). The use, distribution or reproduction in other forums is permitted, provided the original author(s) and the copyright owner(s) are credited and that the original publication in this journal is cited, in accordance with accepted academic practice. No use, distribution or reproduction is permitted which does not comply with these terms. 